\title{
Fragmentation and polymeric complexes of albumin in human urine
}

\author{
Roger C. Wiggins *, Bharati Kshrisagar, Robert C. Kelsch and \\ Barry S. Wilson \\ Departments of Internal Medicine Pediatrics and Pathology, University of Michigan Medical School, Ann \\ Arbor, MI 48109 (USA)
}

(Received December 14th, 1984; revision March 7th, 1985)

Key words: Albumin; Polymer; Fragment

\section{Summary}

Analysis of urine proteins of some individuals with proteinuria by SDS-PAGE and silver staining revealed protein bands in urine which did not appear to be present in plasma. The bands migrated with apparent molecular weights of 260000 , $180000,110000,45000,40000,30000,24000,18000$ and 11000 . These bands were shown to be albumin polymer and fragments by using a polyclonal antibody to (a) immunoprecipitate radiolabelled urine proteins, and (b) identify bands blotted from SDS-PAGE gels onto nitrocellulose paper. The specificity of the polyclonal antialbumin antibody was confirmed by using two mouse monoclonal antibodies raised against human albumin which, between them, recognized the same protein bands on nitrocellulose paper as did the polyclonal antibody. The results of these studies of albumin in human urine confirm that albumin exists as polymer and also show that albumin fragmentation occurs in urine. Fragmentation occurs by proteolysis of the albumin molecule both at sites within and outside disulfide loops. The predominant cleavage site appears to be approximately two-fifths of the distance from one end of the albumin molecule to produce disulfide-linked fragments of about 45000 and 30000 molecular weight.

\section{Introduction}

Electrophoretic analysis of proteins in urine on the basis of protein electrical charge is a useful clinical tool. Recently analysis of urine protein on the basis of size

\footnotetext{
* To whom correspondence should be addressed at: Internal Medicine (Nephrology), D3238 Medical
} Professional Building, University of Michigan Medical Center, Ann Arbor, MI 48109, USA. 
by sodium dodecyl sulfate polyacrylamide gel electrophoresis (SDS. PAGE) has shown that polymers of albumin exist in urine of individuals with nephrotic syndrome [1-3]. However, these studies have also shown that polymerization of albumin occurs mainly as a consequence of freezing urine samples from those individuals taking glucocorticoids [4,5]. The mechanisms responsible for polymerization of albumin are complex and appear to require both modification of the albumin molecule itself as well as the presence of a low molecular weight dialyzable substance in the urine [4,5]. In this study, evidence is provided for the existence of proteolytic modification of albumin in urine.

\section{Materials and methods}

\section{Urine samples}

Urine was obtained from individuals with proteinuria visiting adult or pediatric outpatient clinics. Urine was centrifuged for 5-10 min on a bench top centrifuge. The supernatant was then removed and either analyzed immediately or frozen in a $1.5-\mathrm{ml}$ plastic tube at $-70^{\circ}$ for assay.

\section{Monoclonal antibody production}

Monoclonal antibodies against human albumin were prepared. BALB $/ c$ mice were immunized with human albumin on three occasions over a 3-mth period. Spleen cells were fused with NS-I mouse myeloma cells according to Galfre et al. [6]. Clones were screened using an ELISA assay system in which albumin was bound to the bottom of 96 well Immulon plates (Costar, Cambridge, MA, USA). Bound antibody was detected with alkaline phosphatase conjugated to rabbit antimouse antibody (Cappel Laboratories, Cochranville, PA, USA). Clones producing antialbumin antibody were subcloned by limiting dilution and then further screened for their ability to detect albumin which had been blotted from SDS-PAGE onto nitrocellulose paper. Clones $9 \mathrm{G} 7$ and $2 \mathrm{D} 7$ were selected for growth characteristics and because they recognized albumin blotted onto nitrocellulose paper following analysis by SDS-PAGE under both reducing and nonreducing conditions. Ascites fluid was obtained from pristane-pretreated mice into which clone $9 \mathrm{G} 7$ or $2 \mathrm{D} 7$ cells had been injected i.p. For the experiments described both spent culture medium and ascites fluid were used interchangeably.

\section{SDS-PAGE and blotting}

SDS-PAGE was performed using a micromethod employing the agarose drop technique [7] for loading samples, and a Laemmli buffer system [8]. A discontinuous polyacrylamide gradient was employed capable of separating proteins in the range of 900000-9000 mol wt. Protein was detected by the silver stain technique [9]. Proteins were blotted onto nitrocellulose paper by electrophoretic transfer using a Bio-Rad Transblotting cell (Bio-Rad Laboratories, Richmond, CA, USA). The transfer buffer was Tris $(25 \mathrm{mmol} / \mathrm{l})$, glycine $(192 \mathrm{mmol} / \mathrm{l})$, methyl alcohol $(20 \% \mathrm{v} / \mathrm{v}), \mathrm{pH} 8.3$. The proteins were transferred at $110 \mathrm{~V}$ for $1-2 \mathrm{~h}$ in a refrigerated recirculating water bath. Following the transfer the nitrocellulose paper (cut exactly to the size of the 
gel) was soaked overnight on a rotating mixer in phosphate-buffered saline containing $3 \mathrm{~g} / 100 \mathrm{ml}$ bovine serum albumin (BSA) and $100 \mathrm{ml} / 1$ goat serum. Rabbit antialbumin antiserum (at a $1: 400$ dilution) (Cappel) or mouse monoclonal antihuman albumin antibody was then added to the buffer for $1 \mathrm{~h}$. The paper was then washed five times in PBS to remove unbound antibody. Peroxidase-conjugated rabbit anti-mouse or goat anti-rabbit antibody (Cappel) at a final dilution of $1 / 100$ in the $3 \mathrm{~g} / 100 \mathrm{ml} \mathrm{BSA}, 100 \mathrm{ml} / 1$ goat serum in PBS was incubated with the nitrocellulose blot on the rotating mixer at room temperature for $1 \mathrm{~h}$. Following successive washes in PBS the nitrocellulose blot was developed with 5,5'-diaminobenzedene $\left(1 \mathrm{mg} / 5 \mathrm{ml}\right.$ in $0.1 \mathrm{~mol} / 1$ Tris, $\mathrm{pH} \mathrm{7.4)}$ containing $0.02 \% \mathrm{H}_{2} \mathrm{O}_{2}$. The reaction was stopped by washing out the reactants with deionized water.

\section{Radiolabelling and immunoprecipitation}

Urine samples were dialyzed against $0.1 \mathrm{~mol} / 1$ phosphate-buffered saline, $\mathrm{pH} 7.4$. The dialyzed urine sample $(100 \mu \mathrm{l})$ was mixed with $20 \mu 1$ of ${ }^{125} \mathrm{I}(60 \mathrm{mCi} / \mathrm{ml}$, New England Nuclear, Boston, MA, USA). To this mixture were added two iodobeads (Pierce Chemical Company, Rockford, IL, USA) for $15 \mathrm{~min}$. The beads were removed and the iodinated proteins separated from free iodine by centrifugation through Sephadex G25 (Pharmacia Fine Chemicals, Division of Pharmacia Inc., Piscataway, NJ, USA) to give ${ }^{125}$ I-labelled protein which was approximately $70-90 \%$ precipitable by $30 \%$ trichloroacetic acid and with a spec act of about $1 \mu \mathrm{Ci} / \mu \mathrm{g}$. The ${ }^{125} \mathrm{I}$-labelled protein $\left(10 \mu \mathrm{l}\right.$ urine plus $2 \mu \mathrm{l}{ }^{125} \mathrm{I}$-urine protein $\left.\left(1.6 \times 10^{\mathrm{h}} \mathrm{cpm}\right)\right)$ was then mixed with $10 \mu \mathrm{l}$ rabbit anti-albumin antiserum for $10 \mathrm{~min}$ at $37^{\circ} \mathrm{C}$ followed by $30 \mathrm{~min}$ at $+4^{\circ} \mathrm{C}$ in a $1.5-\mathrm{ml}$ plastic centrifuge tube. To this mixture was added $1 \mathrm{ml}$ $0.1 \mathrm{~mol} / 1$ Tris buffer, $\mathrm{pH} 7.4$, containing $0.15 \mathrm{~mol} / 1 \mathrm{NaCl}$. Following centrifugation at $20000 \times \mathrm{g}$ for $10 \mathrm{~min}$ the supernatant was removed and discarded. The above washing step was repeated. The immunoprecipitate was then suspended in $100 \mu 1$ 10\% SDS containing $8 \mathrm{~mol} / \mathrm{l}$ urea and boiled for $4 \mathrm{~min}$. The samples were divided into two, one portion of which was boiled with $5 \%$ beta-mercaptoethanol. The proteins in these mixtures were then separated by SDS-PAGE (using a $12 \%$ gel). Molecular weight markers (myosin heavy chain, phosphorylase, albumin, ovalbumin, carbonic anhydrase, soybean trypsin inhibitor and lysozyme) were run on the same gels and identified by Coomassie blue staining. The gels were then dried onto blotting paper and bands of radioactivity were detected by autoradiography on Kodak X-Omat AR film (Eastman Kodak Company, Rochester, NY, USA).

\section{Results}

Analysis of urine samples ( $1 \mu l$ unconcentrated urine) from nephrotic individuals by SDS-PAGE under non-reducing conditions showed that there were major protein bands in urine that did not have corresponding bands in plasma (Fig. 1). These bands were present at $260000,180000,110000,45000,40000,30000,18000$ and $11000 \mathrm{~mol} \mathrm{wt}$. Analysis of urine samples showed that reduction of some urine samples with multiple bands at high molecular weight caused these bands to disappear and to leave a major band running at $67000 \mathrm{~mol}$ wt comigrating with 


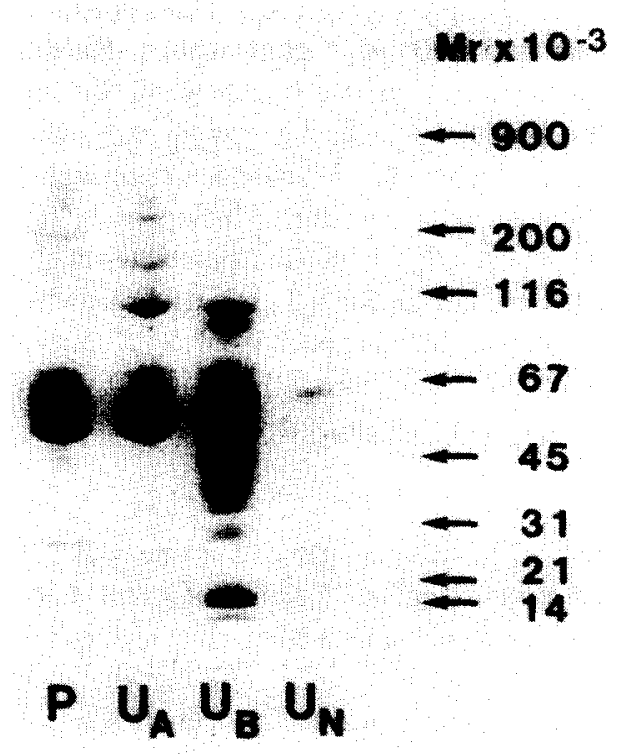

Fig. 1. SDS-PAGE gel run under nonreducing conditions stained for protein by the silver method showing plasma $(P)$, normal urine $\left(U_{N}\right)$, and urine from two individuals with nephrotic syndrome $\left(U_{A}\right.$ and $U_{B}$ ). Note the protein bands which are easily seen in $U_{A}$ and $U_{B}$ but which are not seen in plasma or normal urine.

albumin (Fig. 2, sample $U_{1}$ ). These results suggested that the high molecular weight bands might be polymers of albumin held together by disulfide bonds. However, in other samples reduction produced bands at lower molecular weight than albumin. In some samples (e.g. Fig. 2, sample $\mathrm{U}_{4}$ ) under reducing conditions only a minor band was seen at the albumin position whereas the majority of protein was seen at lower molecular weights $(45000,18000$ and 11000$)$. There were also intermediate examples (as shown in Fig. 2, samples $U_{3}$ and $U_{4}$ ). These results, therefore, suggested that not only was albumin polymerizing but might also be undergoing fragmentation. Therefore, a series of studies were undertaken to determine whether the protein bands observed by SDS-PAGE analysis of urine under reducing and non-reducing conditions were indeed albumin polymer and fragments.

The initial approach used a commercially available polyclonal antialbumin antibody to immunoprecipitate ${ }^{125}$ I-radiolabelled urine proteins. The results of one such study are shown in Fig. 3. In one urine sample (lane A), three major radiolabelled proteins are seen by SDS-PAGE under reducing conditions. However, following immunoprecipitation by anti-albumin antibody only one band is seen at $67000 \mathrm{~mol}$ wt corresponding to albumin (lane B). The anti-albumin serum, therefore, precipitated only ${ }^{125}$ I-protein with the characteristics of native albumin. In contrast the result for a second sample is different. Under reducing conditions in the radiolabelled total urine protein (lane C) major bands were seen at 45000, 40000 and $11000 \mathrm{~mol} w \mathrm{w}$ suggesting that these proteins were not albumin. However, following 


\section{Non-reduced Reduced}



$U_{1} U_{2} U_{3} U_{4}$

\section{$U_{1} U_{2} U_{3} U_{4}$}

Fig. 2. SDS-PAGE gels stained for protein by the silver method run under both reducing and nonreducing conditions on the same gel. Urine $U_{1}$ contains multiple high molecular weight bands which upon reduction disappear to leave a single major hand at $67000 \mathrm{~mol}$ wt. Urine $\mathrm{U}_{4}$ under nonreducing conditions has a very high molecular weight band $(>900000)$ in addition to a band at $60000 \mathrm{~mol} \mathrm{wt}$ which comigrates with albumin. Upon reduction of $U_{4}$ major bands are seen at 45000,18000 and 11000 mol wt. Urines $U_{2}$ and $U_{3}$ also contain high molecular weight bands which disappear on reduction, leaving major bands at the level of albumin (67000) in addition to bands at 45000,30000 and $24000 \mathrm{~mol}$ wt.

immunoprecipitation with anti-albumin anti-serum the same major bands were seen (lane D). These results suggested that the material immunoprecipitated might indeed be fragments of albumin. However, two other possibilities existed. a. The anti-albumin anti-serum might have recognized other proteins apart from albumin in spite of apparently being monospecific as judged by immunodiffusion criteria. $b$. The lower molecular weight bands seen might have represented non-albumin proteins disulfide-linked or otherwise attached to albumin which were precipitated along with albumin or albumin fragments by the anti-albumin serum. To determine whether the bands seen were indeed fragments of albumin a different approach was taken. A series of mouse monoclonal antibodies were raised against human albumin (see 'Materials and Methods'). Two antibodies were chosen to verify that the polyclonal antibody was indeed recognizing fragments of albumin. The proteins in urine samples were first separated by SDS-PAGE, then blotted onto nitrocellulose paper, and finally the protein bands were identified using either the polyclonal or the monoclonal antibodies. Binding of antibodies to antigen on the nitrocellulose paper was identified by using peroxidase-labelled anti-mouse or anti-rabbit antibodies (see 'Materials and Methods' for details). The results of these studies are shown in Fig. 4 for two different urine samples (lanes A, B, and C in one case, and lanes D, E, and F in the other case). As can be seen in Fig. 4 the polyclonal rabbit anti-serum (A) recognized bands at $40000-50000 \mathrm{~mol}$ wt which were recognized by monoclonal 




Fig. 3. Autoradiograms of ${ }^{125}$ I-urine proteins from two individuals analyzed by SDS-PAGE under reducing conditions. Lane B shows the protein immunoprecipitated by antialbumin serum from the total urine protein shown in lane $A$. The single band immunoprecipitated by antialbumin serum migrates at $67000 \mathrm{~mol}$ wt as expected (lane B). In contrast, in another case lane D shows the bands immunoprecipitated from the total radiolabelled urine protein shown in lane $C$. In this second case antialbumin antiserum precipitated major proteins at $40000-45000$ and 11000 , but not at $67000 \mathrm{~mol} \mathrm{wt}$.

antibody $2 \mathrm{D} 7$ (B) but not by antibody $9 \mathrm{G} 7$ (C). On the other hand, antibody $9 \mathrm{G} 7$ (C) recognized bands at 31000,16000 and 11000 which were not seen by antibody 2D7 (B) but were seen by the polyclonal antibody (A). In a second example, the $40000-45000 \mathrm{~mol}$ wt bands seen by the polyclonal antibody (D) were again seen by antibody $2 \mathrm{D} 7$ (E) but not by antibody 9G7 (F), whereas antibody 9G7 (F) again recognized the lower molecular weight bands seen by the polyclonal anti serum (D). Bands at molecular weight higher than albumin monomer were recognized by both monoclonal antibodies as well as the polyclonal anti-serum. In these and in other blotting studies of urine samples, plasma and serum all the bands recognized by the polyclonal anti-serum were recognized by either antibody $2 \mathrm{D} 7$ or antibody $9 \mathrm{G} 7$. We can therefore conclude: (a) that the polyclonal antibody was indeed specific for albumin, (b) that the lower molecular weight bands seen by SDS-PAGE in urine under reducing and non-reducing conditions are fragments of albumin, (c) that the monoclonal antibodies 2D7 and 9G7 recognize different parts of the albumin molecule, and (d) that albumin appears to undergo proteolysis at a site approximately two-fifths of the way from one end of the molecule to produce one family of fragments of about $40000-50000 \mathrm{~mol}$ wt and one family of fragments of about $30000 \mathrm{~mol} \mathrm{wt}$ and smaller. The $30000 \mathrm{~mol} w \mathrm{wt}$ fragment could apparently undergo further cleavage to produce 18000,14000 or 11000 mol wt fragments which were 


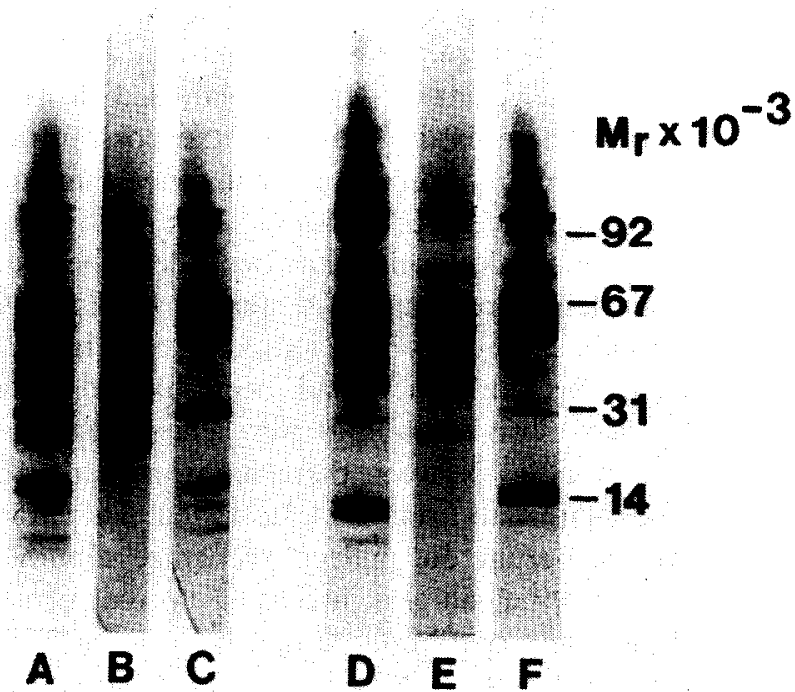

Fig. 4. Nitrocellulose blots from SDS-PAGE gels run under nonreducing conditions. Protein bands were developed by soaking gels in buffer containing antibody, washing free antibody away, and using peroxidase labelled anti-IgG to identify areas of specific antibody binding (see Methods). Blots from two individuals are shown ( A, B, C and D, E, F). Lanes A and D use rabbit anti human albumin polyclonal antiserum. Lanes $C$ and $F$ use mouse anti human albumin monoclonal antibody $9 \mathrm{G} 7$. Lanes $B$ and $E$ use mouse anti human albumin monoclonal antibody 2D7. Note that all the bands are identified by either monoclonal $9 \mathrm{G} 7$ or $2 \mathrm{D} 7$.

still recognized by antibody $9 \mathrm{G} 7$. Antibody $2 \mathrm{D} 7$ recognized the family of fragments of around 40000-50000 mol wt which could also be cleaved to smaller fragments of 28000-30000 mol wt. In summary, using two different methods, the same conclusion was reached, namely that both fragmentation as well as polymerization of albumin in urine had occurred.

\section{Discussion}

Several studies have described polymers of albumin in urine of individuals with nephrotic syndrome [1-5]. In general polymer formation appears to be related to both glucocorticoid treatment and to freezing of urine samples prior to analysis $[2,4]$. In the pediatric population with nephrotic syndrome polymer formation has been suggested to herald steroid responsiveness. This is not true for the adult population [5].

This study has focused on albumin fragmentation in urine of individuals with proteinuria. The study was initially done because large amounts of low molecular weight protein $(<67000)$ on SDS-PAGE analysis of urine is generally thought to indicate that proteinuria is the consequence of renal tubular dysfunction [10]. When it became apparent that the low molecular weight protein was probably albumin studies were done to prove that this was indeed the case. In the first set of studies a 
commercially available polyclonal anti-albumin antibody was used to immunoprecipitate radiolabelled urine proteins which were subsequently analyzed by SDS-PAGE. The results showed that low molecular weight radiolabelled protein were immunoprecipitated by the anti-albumin antibody. However, the possibilities remained that (a) the anti-albumin anti-serum recognized protein other than albumin, or (b) that other proteins were non-specifically precipitated, or (c) that other proteins were disulfide-linked to albumin molecules such a has been described for IgA, IgG, IgM, $\alpha_{1}$ antitrypsin, $\alpha$-lipoprotein, prealbumin or serum amyloid A [11-16]. Therefore monoclonal anti-albumin antibodies were raised against human albumin and used to identify bands of protein which had been blotted onto nitrocellulose paper from SDS-PAGE gels. Two antibodies were chosen from a panel of antibodies raised. These two antibodies between them recognized all the bands identified by the polyclonal anti-serum in all urine samples tested. Therefore we can conclude that the polyclonal anti-serum did indeed recognize albumin fragments in urine. Furthermore, in many urine samples, including normal urine, albumin fragments were present. Fragmentation of albumin might have come from several different sources. Albumin fragments might have been present in blood and passed through the glomerular filter into urine [17]. They may have been partially broken down in proximal tubular cells by cathepsins and exocytosed, or they may have been generated by proteolytic enzymes present in formed urine. These studies do not discriminate between the above possibilities.

The results of the studies using monoclonal antibodies show that albumin fragmentation in urine occurs about two fifths of the way along the polypeptide chain to yield fragments of about 45000 and $30000 \mathrm{~mol} \mathrm{wt}$. These fragments are usually disulfide linked since they are seen when the albumin molecule is reduced (see Fig. 2). However, some fragmentation is also seen in the absence of reducing agents (see Figs. 1 and 4). The smaller $30000 \mathrm{~mol}$ wt light chain could apparently undergo further proteolysis into smaller fragments of 16000 and $11000 \mathrm{~mol}$ wt. The

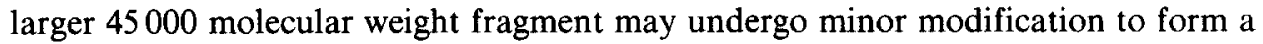
family of 40000-45000 molecules weight fragments. Thus albumin in urine (particularly frozen urine samples) should be considered as a heterogeneous family of proteins including polymers, monomers and also various albumin fragments which may or may not be disulfide-linked. Techniques which are used to study urine proteins and to measure albumin in urine must take these variations into account.

\section{Acknowledgements}

We are grateful to Ms. Catherine Corson for typing the manuscript, to Mrs. M. Marshall for the artwork, and to Mr. Craig Biddle and Mr. Ed Burns for photography. This work was supported by a grant-in-aid from the American Heart Association and the Michigan branch of the American Heart Association and the USPHS Grant AM 30673. Dr. Roger Wiggins is an Established Investigator of the American Hearl Association. Dr Wilson is supported by a Research Cancer Development award (PHS Grant No. 5K04 CA 00845-02) from the National Cancer Institute. 


\section{References}

1 Boeskin WH, Schindera F, Billingham M, White RHR, Williams A. Polymeric albumin in the urine of patients with nephrotic syndrome. Clin Nephrol 1977; 8: 395.

2 Dorman J, Fox J, Hardwicke J. Conditions for albumin dimerization in nephrotic urines. Dependence on an ultrafiltrable factor. Clin Chim Acta 1980; 108: 201.

3 Lubega J. Evaluation of urinary proteins by SDS-PAGE. Clin Chim Acta 1983; 128: 151.

4 Hardwicke J. Clinical significance of urinary albumin dimers in the nephrotic syndrome. Contr Nephrol 1981; 24: 72.

5 Hardwicke J. Proteinuria - the future? Clin Nephrol 1984; 21: 50-53.

6 Galfre G, Howe SC, Milstein C. Antibodies to major histocompatibility antigens produced by hybrid cell lines. Nature (London) 1977; 266: 550-552.

7 Wiggins RC. Agarose drop method for loading thin polyacrylamide gels. Anal Biochem 1982; 126: 422-424.

8 Laemmli UK. Cleavage of structural proteins during assembly of the head of bacteriophage $\mathrm{T}_{4}$. Nature (London) 1970; 227: 680-685.

9 Merril CR, Switzer RC, Van Keuven ML. Trace polypeptides in cellular extracts and human body fluids detected by two-dimensional electrophoresis and a highly sensitive silver stain. Proc Natl Acad Sci USA 1979; 76: 4335-4339.

10 Hardwicke J, Cameron TS, Harrison JT, Holmes B, Soothill JF. Proteinuria in kidney diseases. In: Proteins in normal and pathological urine. Manuel Y, Revillard TP, Betnel H, eds. Basel: Karger, 1970: 111-152.

11 Baumstark JS. Guidelines for the preparative fractionation of human serum proteins on gradient eluted columns of concanavalin A-sepharose: elution positions of fourteen well characterized proteins and evidence for concanavalin A-reactive albumin IgA and IgG complexes. Prep Biochem 1983; 13: 315-345.

12 Ropars C, Doniel $\mathrm{CH}$, Salenn JP. Fixation of albumin to the hinge region of a macroglobulin. Biomedicine 1973; 19: 228-230.

13 Harboe M, Folling I. Complex formation between monoclonal IgM and albumin. Scand J Clin Lab Invest 1974; 3: 51-60.

14 Laurell $\mathrm{C}-\mathrm{B}$, Thulin $\mathrm{E}$. Thiol disulfide interchange in the binding of Bence Jones proteins to $\alpha_{1}$-antitrypsin, prealbumin and albumin. J Exp Med 1975; 141; 453-465.

15 Wille LE, Torsvik H, Kierulf $\mathrm{P}$, Ajone $\mathrm{E}$. Studies on the pre $\alpha$-lipoprotein of human serum. Scand J Clin Lab Invest 1971; 37: 545-549.

16 Rosenthal JC, Franklin EC. Serum amyloid A (SAA) protein-interaction with itself and serum albumin. J Immunol 1977; 119: 630-634.

17 Kshirsagar B, Wilson B, Wiggins R. Polymeric complexes and fragments of albumin in normal human plasma. Clin Chim Acta 1984; in press. 